\title{
Breast Units in Europe - Certification in 9 European Countries 9 Years after the European Society of Mastology Position Paper
}

\author{
F. Andrei Taran Holm Eggemann \\ Universitätsfrauenklinik, Otto-von-Guericke-Universität Magdeburg, Germany
}

\author{
Key Words \\ Breast units · Breast cancer - Certification criteria
}

\section{Summary}

Introduction: We aimed to take a snapshot of breast units in the European Union 9 years after the publication of the European Society of Mastology (EUSOMA) position paper. Methods: In order to obtain information on breast units throughout the European Union, we designed a questionnaire comprising 5 questions on certification, audit frequency and number of breast units in each country. Our primary contacts were national cancer societies, breast cancer study groups, breast cancer organizations, national associations and societies of breast treatment, as well as experts in the field of breast cancer. Results: Information on characteristics of the certification process and number of breast units was obtained for 9 countries of the European Union. 7 of the 9 countries (78\%) have a certification process of the breast units. Certification is carried out by public authorities in $4(57 \%)$ countries and by private companies in $3(43 \%)$ countries. Information on frequency of auditing was reported in 4 countries and varied between annual audits (Austria, Ireland and Germany) and audits once every 3 years (United Kingdom). Conclusions: The current study suggests that the European breast unit landscape is a heterogeneous field. 9 years after the EUSOMA position paper, we do not have any standard European guidelines, neither for the development nor for the mandatory prerequisites of a breast unit. The development and operation of breast units are still country specific.

\author{
Schlüsselwörter \\ Brustzentren · Mammakarzinom · Zertifizierung
}

\section{Zusammenfassung}

Hintergrund: 9 Jahre nach der Veröffentlichung des Positionspapiers der European Society of Mastology (EUSOMA) wollten wir eine Momentaufnahme der Brustzentren in Europa machen. Methoden: Um Informationen über Brustzentren aus der Europäischen Union zu erhalten, wurde ein Fragebogen über Zertifizierung, Häufigkeit der Zertifizierung und Anzahl der Brustzentren in jedem Land entwickelt. Unsere primären Ansprechpartner waren sowohl nationale Krebsgesellschaften, Studiengruppen, nationale Organisationen und Gesellschaften für die Therapie der Brusterkrankungen als auch Experten für die Therapie und Diagnostik des Mammakarzinoms. Ergebnisse: Informationen über Charakteristika der Zertifizierung und Anzahl der Brustzentren wurden aus 9 Ländern der Europäischen Union erhalten. In 7 der 9 Länder (78\%) findet eine Zertifizierung der Brustzentren statt. Die Zertifizierung wird durch staatliche Behörden in 4 (57\%) Ländern durchgeführt und durch private Unternehmen in $3(43 \%)$ Ländern. Die Häufigkeit der Zertifizierungen variiert zwischen jährlichen Audits (Österreich, Irland und Deutschland) oder 3-jährlichen Audits (Großbritannien). Schlussfolgerungen: Unsere Studie verdeutlicht die heterogene Landschaft der Brustzentren in Europa. 9 Jahre nach dem Positionspapier der EUSOMA gibt es keinen europäischen Standard, weder in der Entwicklung noch in der Organisation eines Brustzentrums. Die Entwicklung und Organisation eines Brustzentrums bleiben weiterhin länderspezifisch.

\begin{tabular}{ll}
\hline KARGER & $\oplus$ 2009 S. Karger GmbH, Freiburg \\
Fax +497614520714 & Accessible online at: \\
Information@Karger.de & www.karger.com/brc \\
www.karger.com &
\end{tabular}




\section{Introduction}

Breast cancer is the most common malignancy in women, accounting for $\sim 25 \%$ of all female cancers. Incidence is highest in northern Europe and declines from the north to the south of the continent [1]. The EUROCARE-3 and EUROCARE4 studies showed that breast cancer has variation in survival with geography: highest in Nordic countries (except Denmark) and Central Europe, intermediate in Southern Europe, lower in the United Kingdom (UK) and Ireland and lowest in Eastern Europe [1,2].

If breast cancer survival in one country is lower than in other countries, especially those of similar wealth, the health care system is probably not functioning as it should. Reasons for this problem might be late diagnosis, inadequate availability or poor access to treatment. The European Society of Mastology (EUSOMA) Working Group published in 2000 guidelines for the development and operation of state-of-theart multidisciplinary breast units. The requirement of a breast unit was a quality assurance plan with the overall goal of improving breast care for women with both benign and malignant disease [3]. Moreover, the European Parliament issued a report on breast cancer in 2003 demanding the establishment of European guidelines for the certification of breast units in order to prevent an inflation of breast units without the required quality standards [4].

The current study aims to take a snapshot of breast units in the European Union 9 years after the publication of the EUSOMA position paper and 6 years after the report on breast cancer of the European Parliament. Information on the number of breast units and their certification process will allow us to examine whether the European Union is moving towards a common standard of breast units.

\section{Methods}

In order to obtain information on breast units throughout the European Union, we designed a questionnaire comprising 5 questions on certification, audit frequency and number of breast units in each country (table 1). This questionnaire-based study was carried out between September 29, 2008 and June 4, 2009.

Our primary contacts were national cancer societies, breast cancer study groups, breast cancer organizations, national associations and societies of breast treatment, as well as experts in the field of breast cancer. Questioning was carried out in English by phone calls and the questionnaire was also sent out by e-mail. The overall response rate to the questionnaires was very low. Only $8 \%(4 / 51)$ of the persons contacted by phone answered the questionnaire and only $5 \%$ (5/108) of the questionnaires sent by e-mail were answered. There was no difference regarding response rates and contacted sources (data not shown).

Information on breast units was obtained from 9 (33\%) countries of the European Union: Austria, Germany, Ireland, Iceland, Norway, Spain, Sweden, The Netherlands and the UK. Information was obtained from the following national cancer societies (Icelandic Cancer Society and Dutch Cancer Society), breast cancer study groups (Austrian Breast and Colorectal Cancer Study Group (ABCSG), Grupo Español de Investi-
Table 1. Questions on breast units in countries of the European Union

1. Do breast units in your country require a certification process?

2. If yes, is certification provided by public authorities or private companies?

3. How frequent is auditing?

4. What is the number of breast units in your country?

5. Is a maximum number of breast units determined?

gación en Cáncer de Mama (GEICAM), Swedish Breast Cancer Study Group), breast cancer organizations (Breast Cancer Care United Kingdom and Breast Cancer Ireland), the Association of Breast and Endocrine Surgeons in Norway and the German Society of Senology.

'SenoNetwork' is a joint project of the European School of Oncology, EUSOMA and Cancerworld.org. It is a network of clinical centers exclusively dedicated to the diagnosis and treatment of breast cancer as defined by EUSOMA [5]. In order to identify the breast units included in this network, we accessed the Breast Units Directory of 'SenoNetwork' [6].

\section{Results}

The characteristics of the certification process and the numbers of breast units in 9 countries of the European Union are presented in table 2.7 of the 9 countries $(78 \%)$ have a certification process of the breast units. Certification is carried out by public authorities in $4(57 \%)$ countries and by private companies in $3(43 \%)$ countries. Information on frequency of auditing was reported in 4 countries and varied between annual audits (Austria, Ireland and Germany) and audits once every 3 years (UK) (table 2).

Regarding the exact number of breast units, we received data on 7 (78\%) countries (table 2). A special case represents Austria with a total of 8 breast units. 3 units were certified by a German company and 5 were certified by an Austrian company. In the UK there are 500 hospitals that participate in the formation of cancer networks. The breast units are part of the networks, with every specialization field (i.e. oncologist, radiologist, pathologist) having its own lead clinician. The breast units in The Netherlands are part of 8 national Cancer Comprehensive Centers.

A maximum number of planned breast units has been reported for $5(5 / 9,56 \%)$ countries. The model of care for these countries is in most cases aligned to the EUSOMA guidelines, with 1 breast unit serving a population of approximately $250,000-300,000$. The only exception is Ireland with 8 breast units for 4.3 million inhabitants and thus resulting in 1 breast unit for a population of over 500,000 [7].

The European breast units listed by SenoNetwork are presented in table 3 . The directory comprises a total of 77 breast units from 16 European countries. All countries but Turkey $(15 / 16,94 \%)$ are members of the European Union. The country with the most listed breast units is Germany with 21 breast 
Table 2. Characteristics of the certification process and number of breast units in 9 countries of the European Union

\begin{tabular}{|c|c|c|c|c|c|}
\hline Country & $\begin{array}{l}\text { Breast units } \\
\text { certification } \\
\text { process }\end{array}$ & $\begin{array}{l}\text { Certification } \\
\text { authorities / } \\
\text { companies }\end{array}$ & Audit frequency & Number of breast units & $\begin{array}{l}\text { Maximum number } \\
\text { of planned units }\end{array}$ \\
\hline Austria $^{\mathrm{a}}$ & yes & private & annually & 8 & 30 \\
\hline United Kingdom $^{\mathrm{b}}$ & yes & public & every 3 years & $\begin{array}{l}\text { approx. } 500 \text { hospitals participate in the } \\
\text { formation of cancer networks (every field } \\
\text { within a network has its own lead clinician) }\end{array}$ & - \\
\hline Ireland ${ }^{\mathrm{c}}$ & yes & public & annually & 8 & 8 \\
\hline Iceland $^{\mathrm{d}}$ & yes & public & - & 1 & 1 \\
\hline The Netherlands ${ }^{\mathrm{e}}$ & yes & public & - & 8 Comprehensive Cancer Centers & - \\
\hline Sweden ${ }^{\mathrm{f}}$ & no & - & - & 5 in West Sweden & 5 \\
\hline Spain $^{\mathrm{g}}$ & yes & private & - & 80 & - \\
\hline Norway $^{\text {h }}$ & no & - & - & 19 & 19 \\
\hline Germany $^{\mathrm{i}}$ & yes & private & annually & 182 & - \\
\hline
\end{tabular}

${ }^{\mathrm{a} B C S G}$.

${ }^{\mathrm{b}}$ Breast Cancer Care.

${ }^{\mathrm{c} B r e a s t}$ Cancer Ireland.

${ }^{\mathrm{d}}$ Icelandic Cancer Society.

${ }^{\text {e}}$ Dutch Cancer Society.

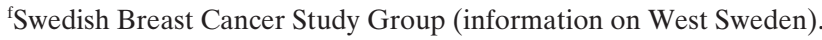

${ }^{\mathrm{g}}$ GEICAM.

${ }^{\mathrm{h}}$ Association of Breast and Endocrine Surgeons in Norway.

${ }^{\mathrm{i}}$ German Society of Senology.

Table 3. European breast units directory listed by

SenoNetwork ${ }^{\mathrm{a}}$

\begin{tabular}{|c|c|c|c|c|c|}
\hline Country & $\begin{array}{l}\text { Number of } \\
\text { breast units }\end{array}$ & $\begin{array}{l}\text { Certified by } \\
\text { EUSOMA }^{\mathrm{b}}\end{array}$ & $\begin{array}{l}\text { Applied for } \\
\text { EUSOMA }^{\mathrm{b}} \\
\text { certification }\end{array}$ & $\begin{array}{l}\text { Newly treated } \\
\text { cases per year, } \\
\text { range (mean) }\end{array}$ & $\begin{array}{l}\text { Dedicated breast } \\
\text { surgeons, } \\
\text { range (mean) }\end{array}$ \\
\hline Austria & 1 & 1 & - & 337 & 3 \\
\hline Belgium & 17 & - & 2 & $150-700(288)$ & $2-6(3)$ \\
\hline Bulgaria & 1 & - & - & 180 & 2 \\
\hline Czech Republic & 1 & - & - & 356 & 1 \\
\hline France & 2 & - & - & $300-816(558)$ & $3(3)$ \\
\hline Germany & 21 & 18 & 1 & $188-600(332)$ & $2-8(4)$ \\
\hline Hungary & 1 & - & - & 350 & 2 \\
\hline Italy & 11 & - & 2 & $166-2500(717)$ & $1-17(5)$ \\
\hline Luxembourg & 1 & - & - & 150 & 3 \\
\hline Portugal & 3 & - & - & $150-671(357)$ & $2-10(5)$ \\
\hline Slovenia & 1 & - & - & 600 & 5 \\
\hline Spain & 5 & - & - & $180-218$ (194) & $2-5(4)$ \\
\hline Switzerland & 4 & 2 & - & $100-220(155)$ & $2-6(4)$ \\
\hline The Netherlands & 3 & - & - & $172-500(326)$ & $2-3(3)$ \\
\hline Turkey & 2 & - & - & $152-200(176)$ & $1-2(2)$ \\
\hline United Kingdom & 3 & - & - & $257-400(312)$ & $3-4(3)$ \\
\hline Total number & 77 & 21 & 5 & $100-2500(337)$ & 1-17 (3) \\
\hline
\end{tabular}

${ }^{\mathrm{a}}$ www.senonetwork.org; accessed June 13, 2009.

${ }^{\mathrm{b}}$ European Society of Mastology. units. Austria, Bulgaria, the Czech Republic, Hungary, Luxembourg and Slovenia have each 1 breast unit listed. Out of the 77 breast units, 21 (27\%) were certified by EUSOMA and $5(6 \%)$ have applied for EUSOMA certification. Germany has also the highest number (18) of EUSOMA-certified breast units (table 3).
The range of newly treated cases per year for all listed breast units ranges from 100 to 2500 cases, with a median of 337 cases per breast unit. There is a reported range for all listed breast units of 1 to 17 dedicated breast surgeons, with a median of 3 surgeons per breast unit (table 3 ). 


\section{Discussion}

The current study suggests that the European breast unit landscape is a heterogeneous field and that gathering information on breast units from European countries is a tedious process. In some countries breast units do not require any certification or auditing procedures. In countries with certified breast units, the certification process is carried out by public authorities as well as private companies and the auditing frequency varies.

Nine years after the EUSOMA position paper and 6 years after the report on breast cancer of the European Parliament, we do not have any standard European guidelines, neither for the development nor for the mandatory prerequisites of a breast unit. The development and operation of breast units are still country specific.

The EUSOMA Working Group estimated that, for a 10 million population base, $30-40$ breast units would be required in order to provide adequate breast cancer diagnosis and treatment [3]. Assuming a current European population of 500 million inhabitants, a total of approximately 1500-2000 breast units would be necessary to reach this goal. The breast unit directory of SenoNetwork contains only 77 breast units from 16 European countries. This number is by far too low to enable a thorough analysis of the current European situation.

However, since the EUSOMA position paper does not take into account regional differences in breast cancer practice, applying these concepts all over Europe will prove difficult [8]. Thus, it is unlikely that the number of breast units included in the SenoNetwork directory will increase dramatically during the next few years. Therefore, other options of networking will have to be taken into consideration.

A major limitation of the current questionnaire-based study is the extremely low response rate. Several alternative explanations of this situation are conceivable. First, the language barrier might have played an important role since the questionnaire was designed in English. Second, the multitude of information sources unmasks further diversity in regional breast care. While in some countries information on breast units was successfully obtained from national cancer societies, this was impossible in other countries where such information was not available at the cancer societies. We obtained data on 9 countries from 5 different sources. Hence, some potentially relevant information sources might have been missed.

All countries of the European Union face similar challenges when providing adequate and high-quality treatment for breast cancer. It is unclear whether a common European standard would be useful to improve the care provided to patients and to narrow the present gap in survival variation. Nevertheless, introduction and dissemination of standard European guidelines for the development and operation of breast units might facilitate networking and benchmarking processes.

\section{Conclusions}

Our study provides an overview on the diversity of breast units in Europe. Such an overview has limitations due to the lack of a database and/or a central registry. At the present time, we can only state that at least in 9 European countries breast units are built and function according to own, specific criteria. There is no doubt that establishing interdisciplinary breast units will lead to an improvement of patient care in breast cancer, because interdisciplinarity and defined pathways in diagnosis and therapy are important prerequisites in conveying optimum treatment for breast cancer. If we all aim at improving survival of breast cancer patients - and we all certainly do so! - benchmarking should be one of the tools useful in comparing our own results with those in other centers and countries. We therefore hope that senological societies from European countries will get together as soon as possible in order to gather valid data and try to standardize the structural and organizational processes in breast care.

\section{Conflict of Interest}

There are no conflicts of interest to report.

\section{References}

1 Sant M, Aareleid T, Berrino F, Bielska Lasota M, Carli PM, Faivre J, Grosclaude P, Hédelin G, Matsuda T, Møller H, Möller T, Verdecchia A, Capocaccia R, Gatta G, Micheli A, Santaquilani M, Roazzi P, Lisi D: EUROCARE-3: survival of cancer patients diagnosed 1990-94 - results and commentary. Ann Oncol 2003;14:61-118.

- 2 Berrino F, De Angelis R, Sant M, Rosso S, Bielska-Lasota M, Coebergh JW, Santaquilani M: Survival for eight major cancers and all cancers combined for European adults diagnosed in 1995-99: results of the EUROCARE-4 study. Lancet Oncol 2007;8:773-783.
The EUSOMA position paper on the requirements of a specialist breast unit. Eur J Cancer 2000;36:2288-2293.

4 Bericht über Brustkrebs in der Europäischen Union (2002/2279(INI)). Ausschuss für die Rechte der Frau und Chancengleichheit. Berichterstatterin: Karin Jöns. Europäisches Parlament, 7. Mai 2003.

5 www.senonetwork.org/; accessed June 13, 2009.

6 http://senonetwork.org/AllLanguages/Menu1/Breast UnitsDirectory.asp? SelectionMenu $=-10$; accessed June 13, 2009.
7 www.cso.ie/statistics/popnbyage2006.htm; accessed June 13, 2009

8 Silverstein MJ: State-of-the-art breast units - a possibility or a fantasy? A comment from the US. Eur J Cancer 2000;36:2283-2285. 